\title{
Both Sides of the Looking Glass: Librarian and Teaching Faculty Perceptions of Librarianship at Six Community Colleges
}

\author{
Devin Feldman and Susan Sciammarella
}

\begin{abstract}
Librarians and teaching faculty often have different perceptions of the roles of the library and the librarian in undergraduate education. A study surveying six community colleges reveals that there is much room for improvement in the interrelationship between librarians and teaching faculty. More effective communication and mutual respect would enhance the educational experience for students and provide a richer learning environment.
\end{abstract}

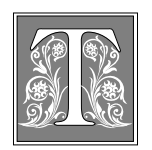

he concept for this study developed over the past few years through conversations the authors had with library colleagues. Topics frequently discussed included reference questions, bibliographic instruction (BI) classes, and relationships with teaching faculty. This group of librarians often expressed dissatisfaction in both interactions with teaching faculty and the types of sources teaching faculty asked students to use to complete assignments. In the course of attempting to define the librarian's role in teaching bibliographic instruction and providing general reference service, it became apparent that the librarians felt that their professional expertise in the field of library science was underappreciated and misunderstood by the teaching faculty. Out of concern for these issues, the authors developed a survey to determine whether these ex- periences and impressions were unique to this group of colleagues or whether they applied to the broader spectrum of library professionals. In addition, the authors created a survey to send to teaching faculty in an attempt to better understand their perceptions of librarians and librarianship.

The survey was conducted in February/March 2000 at The City University of New York and sent to its six community colleges. Because the authors work in a community college, they wanted to survey colleagues in academic settings similar to their own. The colleges surveyed were Borough of Manhattan Community College, Bronx Community College, Eugenio Maria de Hostos Community College, Kingsborough Community College, Fiorello H. LaGuardia Community College, and Queensborough Community College. A total of 500 surveys were sent as a sampling to both librarians

Devin Feldman is an Assistant Professor and Susan Sciammarella is an Adjunct Assistant Professor in the Kurt R. Schmeller Library at Queensborough Community College of The City University of New York; e-mail: DFeldman@ qcc.cuny.edu and baaqb@cunyvm.cuny.edu, respectively. 
and teaching faculty. The teaching faculty, both full- and part-time, were sent 425 surveys. The librarians, likewise both fulland part-time, were sent a total of seventy-five surveys.

\section{Librarians must reaffirm and emphasize the importance of their roles as teachers in the academic community.}

The departments chosen for the survey were those whose faculty were most likely to schedule bibliographic instruction, which included the departments of English, history, music, sociology, psychology, anthropology, political science (government), philosophy, ethics, religion, speech/theater arts, economics, business, and nursing. Of the total number of surveys sent, the teaching faculty had a return rate of 37 percent and the librarians a return rate of 69 percent.

In sharing these responses, the authors hope to better define librarians as professionals in their field and to better understand the teaching faculty with whom librarians have a common interest-the students.

\section{Role/Image of the Librarian and Librarianship in the Academic Library}

Providing reference service is a critical part of the librarian's job. Librarians also are collection specialists, catalogers, BI teachers, and circulation managers, to name just a few more of their many responsibilities. The librarians' daily work environment requires them to be multifaceted. They are in a field that changes every day because information changes every day. Consequently, librarians are always on the information highway. They must know how to access and interpret that highway to provide fast responses for ready reference. In addition, they must navigate the myriad licensed resources that keep multiplying and must be knowledgeable about current events. The librarians at The City University of New York have faculty status and must obtain a second master's degree for tenure in addition to producing scholarly work.

Librarians are categorized as nonteaching faculty, even though they teach BI classes. The authors' survey revealed that 80 percent of the librarian respondents felt that their nonteaching status was inappropriate in light of the fact that they teach classes on the techniques of academic research and 84 percent felt that recognizing them as teaching faculty would help improve the status of the librarian in the academic community.

Librarians must reaffirm and emphasize the importance of their roles as teachers in the academic community. "Librarians need to perform in the classroom at the same level of teaching as the rest of the faculty. They must be articulate and dynamic. They must sell a message." ${ }^{\prime 1}$ The key words in this quote are "sell a message." Is the message that librarians want to sell the importance of the BI class, the significance of their role in communicating the invaluable skills of academic research, or both?

Librarians are always concerned with increasing the value of their role within the college community. The survey showed that 67 percent of the librarian respondents hold a second master's degree, 44 percent have conducted research in their field and/or have published in the past five years, and 77 percent have taken continuing education courses, seminars, or colloquiums on advanced information sources within the past two years. Forty-eight percent have served as a library liaison to an academic department. In contrast, only 21 percent of the teaching faculty have served as a liaison from their department to the library. Moreover, 52 percent of the librarians have served as members of the faculty on an academic senate or other college committee.

What can librarians do to better promote themselves and the field of librarianship to the teaching faculty? The survey overwhelmingly showed that 92 percent of the librarians felt that teaching faculty are unaware of the nature of the 
field of library science/information technology and 94 percent believed that teaching faculty who assign research papers are unfamiliar with the use of current research tools available to their students in the library. Yet, 90 percent of the teaching faculty surveyed said they are familiar with the reference, circulating, and periodical sources available in the library for their classes. The indications are clear in terms of how librarians perceive the teaching faculty and how teaching faculty view the library. Neither group has the complete picture.

To establish a more balanced working relationship, accommodating teaching faculty becomes a necessity. In her 1997 article, "What I Want in a Librarian," Aletha D. Stahl, a member of the teaching faculty of Earlham College, expressed the need for clear communication:

I particularly need clear communication concerning the limits of a librarian's time and energy in advancing my research.... I need clear communications about the particular library in which you work.... It is equally important that you inform and keep informing me about resources in and beyond the library.... I appreciate learning as soon as possible to whom I should go with questions related to my research, books on reserve electronic resources, collection development, instruction for my classes ... please communicate clearly to me the human layout of the library. ${ }^{2}$

Striving for effective communication is a positive beginning. It is important to find common ground for both librarians and teaching faculty. As professionals in the academic community, they share the same interests in teaching and learning. The librarian must talk with faculty about sources, promote the BI classes, and demonstrate his or her expertise in the very specialized field of library and information science (LIS) just as the teaching faculty member would with his or her subject specialty. Stahl stated: “Maybe we can learn from each other: I need your experience and knowledge of a range of tools, but as a subject area specialist, I may have good reasons for my ingrained preferences.... My greatest empowerment may come from observing your approach to my questions." ${ }^{3}$ Armed with LIS degrees and equipped with the ability to provide answers to teaching faculty's questions, librarians are doubly empowered.

Even so, it is sometimes difficult to escape the negative light in which librarians are often portrayed in today's media-conscious society. John Cullen, a librarian at the Institute of Technology in Ireland, recently wrote in American Libraries that librarians' images on television and in the movies are far from positive. In the popular television show Buffy, the Vampire Slayer, the school librarian "provides one of the most negative and oversimplified images of a librarian ever depicted by the entertainment industry." Librarians have been characterized as "murderous" in The Name of the Rose, "dizzy" in The Mummy, and "unhelpful and ineffective" in a large segment of media portrayals of the profession. ${ }^{5}$

\section{Eighty-eight percent of the librarians reported that conflict often exists between assignments and research sources available in the library.}

The patron's image of the librarian and librarianship also is important to the librarian. The patrons are the librarian's business and, again, the librarians must sell the message. This time, however, the message is the accurate image of what a librarian is and what he or she actually does in the library. "If future politicians, university deans, and other fund managers are brought up on a diet of popular movies and TV shows that never realistically portray the services librarians offer, none of them will value our skills and expertise enough to keep us in business." 6

\section{Bibliographic Instruction}

Much of the literature on bibliographic instruction states that librarians and some of the teaching faculty in academic institutions view it as an essential tool in providing undergraduate students, particu- 
larly freshmen, with critical research skills. However, over 64 percent of The City University of New York's community college teaching faculty responded that they did not make use of the BI classes offered by their libraries. Of those who did not use this service, 21 percent were unaware that BI classes were available; 12 percent felt that students should know how to do research and write a college paper; 25 percent responded that students could seek assistance from the faculty member; and 25 percent told the students to ask for help from the librarian. The responses of 17 percent of faculty members surveyed fell into the "other" category. In this category, several responded that there is not enough time for library instruction, some said that teaching faculty members teach library skills themselves, two expressed dissatisfaction with the BI classes, and one wrote: "I thought this was done in basic English classes."

The results of this survey concur with similar surveys conducted in academic environments. One such survey conducted at the University of Manitoba "revealed that ... faculty do not view librarians as major contributors to the educational process." ${ }^{7}$ Larry Hardesty described some of the reasons for this attitude in his 1995 article, "Faculty Culture and Bibliographic Instruction: An Exploratory Analysis." He felt that bibliographic instruction would be most successful if teaching faculty would take a more active role.

Many librarians view the library as a tremendous educational resource that is not fulfilling its potential. They believe that much more could be accomplished if only faculty would co-operate more with them. In the midst of scholarly wealth, there is the perception of intellectual poverty because students do not know how to use academic libraries.... Faculty must be involved for the success of bibliographic instruction. ${ }^{8}$
This emphasis on the effectiveness of faculty involvement in teaching library skills also was reflected in the answers on the authors' surveys. Of the librarians who teach bibliographic instruction, 77 percent said they have the opportunity to discuss the nature of the class they will be teaching with the faculty member and 84 percent felt they are in a collaborative partnership with the teaching faculty. Although 78 percent felt their library promotes classes well, there is clearly still room for improvement.

Of the 36 percent of teaching faculty who bring their classes to the library for instruction, 75 percent responded that verbal interaction with the librarian is necessary to have an effective lesson. Filling out a form with information about an assignment for which a library class is requested was preferred by 25 percent. And 71 percent of the teaching faculty who use a BI program felt that it is important to accompany their class to the library. This is a fairly good percentage of teaching faculty who seem to feel that their presence and input are necessary for an effective BI class. From the librarian's standpoint, 94 percent felt that an initial contact between teaching faculty member and librarian is important to understand the exact nature of the class that will take place. In addition, 82 percent felt that it is part of the librarian's responsibility to clarify the resources available in the library and the nature of the lecture to be given by the librarian. Therefore, again, communication is at the heart of an effective library lesson.

Despite the fact that a high percentage $(64 \%)$ of teaching faculty does not use formal bibliographic instruction to help their students develop library skills, 63 percent of the teaching faculty responded that they do give assignments mostly for the purpose of introducing students to the library. This is important to note because even an assignment to locate books or an article on a particular topic can be an effective beginning to student library use, particularly for a course where a research paper is not being done. 
The problems that the authors' survey revealed among both teaching faculty and librarians in the six City University of New York community colleges do not appear to be unique. The literature reflects, again and again, that teaching faculty often feel the pressures of time constraints, and although they encourage students to develop library skills, many resist the idea of devoting class time to this purpose. "Faculty members consider time of critical importance. They never have enough.... Student library use is not a matter of time. It is a matter of values. Many faculty we interviewed (at seven different institutions ranging from small private colleges to major research universities) did not value the library's contribution to undergraduate education." ${ }^{\prime 9}$ This attitude is most apparent when examining faculty behaviors toward bibliographic instruction.

When Eugene A. Engeldinger, director of library services at Carthage College in Wisconsin, addressed the Wisconsin Library Association in 1992, he offered one explanation for the low regard with which the library is often held: "Most faculty believe library skills are useful for students to have and they believe that librarians know how to use the library, but they wonder if librarians can really do research-or teach for that matter."10 In his paper, he raised other questions about the effectiveness of bibliographic instruction and looked at the possible reasons for its failure to meet both faculty and student needs. "Do we fail to understand the purpose of the assignment and talk about irrelevancies? If so, is it because we have not fully understood faculty needs or do we need to educate faculty as to the real needs of their students and how we can effectively satisfy them?"11

\section{Assignments and Sources}

Although lack of communication between librarians and teaching faculty is obviously a major contributor to less-than-successful BI programs, poor communication causes problems at the reference desk as well. Eighty-eight percent of the librarians reported that conflict often exists between assignments and research sources available in the library. Some of the types of materials where problems are found include the number of sources required $(28 \%)$, Internet sources (19\%), and outdated sources (26\%). Librarians' comments on other areas of conflict were: "Library's resources or available literature (that) cannot answer the question or require greater research skills than students have"; whole classes needing to take out a book on a very specific topic"; "we just do not get the journals they need." Yet, the authors' survey indicated that only 48 percent of the librarians had contacted faculty members to let them know that a source was unavailable. Interestingly, the teaching faculty responded overwhelmingly (91\%) that they were willing to be flexible in the types of sources a student could use for an assignment or research paper. This is a good example of how critical communication can be. Granted, it takes time to contact a member of the teaching faculty; but if a dialogue does not take place between librarian and teaching faculty, the student becomes the frustrated loser and the teaching faculty will carry their lack of knowledge from one semester to the next. Here again, effective communication would go a long way toward improving the results. When librarian Richard Hume Werking interviewed faculty at Lawrence University to determine how to provide them with the most effective reference service, he found that "They generally agreed that it might be a good idea if the librarians and faculty worked together to educate the students about the range of resources in the library that were relevant for their assignments, and how to go about tapping those resources."12

Kenneth E. Carpenter, a librarian at Harvard University, quoted Professor Karl Weintraub who "urges that librarians avoid the temptation to withdrawal ... 'in isolation as if they were a beleaguered community of martyrs.... And since library matters seem of the greatest moment to librarians, it is they who will have to take the initiative in opening lines of 
communication, they who must invite rather than according to their custom, avoid faculty commentary.'"13

Computer technology has had a strong impact on the role of the librarian. In truth, teaching faculty need librarians more than in the past. One adjunct member of the teaching faculty surveyed wrote: "I have severely under-utilized the library. I am not fond of the computers and the two times I went to the library, the computers were down." This is a common reaction among teaching faculty to the constantly evolving academic library. Many teaching faculty members had completed several degrees before the information technology explosion. They used printed indexes for their research. Now, they must learn a whole new set of rules for doing research-if not for themselves, then at least for their students. They must be aware of what is available through the Internet and how to evaluate and utilize such resources. Moreover, they are not always eager to learn the new skills. Only 35 percent of the teaching faculty said they had attended seminars on how to access technological sources offered by their library. Although they obviously could have taken courses in other locations, their own college library would be the natural place to learn how to use the resources specifically available on their campus.

However, even though they did not participate in formal instruction, 69 percent of the teaching faculty surveyed said they had contact with the librarians in their college library regarding their own or their students' research and 82 percent felt their college librarian was able to assist them in gathering information for their research. Moreover, 77 percent claimed to know how to access their subject specialty on the Internet and 63 percent indicated they were familiar with most of the research tools and methods being taught to the students by the librarian.

These percentages indicate that, overall, the library and the librarians are considered valuable resources by the teaching faculty who responded to the survey.
The fact that they answered the questions and returned the survey shows that the library matters to them. For the 63 percent of the teaching faculty who did not return the survey, this too makes a statement.

\section{Conclusion}

As previously stated, this survey was undertaken to better understand both teaching faculty and librarians, and their interrelationship. Community colleges deal with a particular type of student, one often with multiple responsibilities-family, job, and limited finances. A college education is one way that such students choose to better themselves and the lives of their families.

Community colleges make up onethird of The City University of New York. The community college plays an integral role in the undergraduate educational process, often serving as a stepping-stone to a four-year degree or providing complete career training in the two years alone. The authors learned that the librarians in the six community colleges surveyed are a highly committed group. They continue to educate themselves on the latest professional developments, and they network with their colleagues whenever they have the opportunity. They also interact within their college community, serving as liaisons to academic departments and members of collegewide committees and generally staying visible and vocal outside the library.

Many of The City University of New York's community college teaching faculty are coping with the usual academic problems, one of which is not enough time to cover what they have to in any given semester. They do not use the library to its fullest potential. It is the obligation of librarians to enlighten the teaching faculty with what they can offer them and their students. Librarians can train teaching faculty how to meet whatever information needs they have and can help stimulate ongoing dialogue between the library and the other academic departments. As longtime librar- 
ian Evan Farber stated: "for the teaching library to succeed close collaboration between librarians and faculty (is) necessary." ${ }^{14}$ Through effective communica- tion and partnering with teaching faculty, librarians can make important contributions to higher education in the new millennium.

\section{Notes}

1. Larry Hardesty, Faculty and the Library: The Undergraduate Experience (Norwood, N.J.: Ablex, 1991), 115.

2. Aletha D. Stahl, "What I Want in a Librarian: One New Faculty Member's Perspective," Reference E User Services Quarterly 37 (winter 1997): 133.

3. Ibid., 134-35.

4. John Cullen, "Rupert Giles, the Professional-image Slayer," American Libraries 31 (May 2000): 42.

5. Ibid.

6. Ibid.

7. Robert T. Ivey, "Teaching Faculty Perceptions of Academic Librarians at Memphis State University," College $\mathcal{E}$ Research Libraries 55 (Jan. 1994): 71.

8. Larry Hardesty, "Faculty Culture and Bibliographic Instruction: An Exploratory Analysis," Library Trends 44 (fall 1995): 361.

9. - Faculty and the Library, 30.

10. Eugene A. Engeldinger, "Frustration Management in a Course-Integrated Bibliographic Instruction," RQ 32 (fall 1992): 22.

11. Ibid., 23.

12. Richard Hume Werking, "A Critical Look at Possibilities for and Obstacles to Library Use," $R Q 31$ (winter 1991): 162.

13. Kenneth E. Carpenter, “The Librarian-Scholar,” Journal of Academic

Librarianship 23 (Sept. 1997): 399.

14. Evan Farber, "College Libraries and the Teaching/Learning Process: A 25-Year Reflection," Journal of Academic Librarianship 25 (May 1999): 173. 